\title{
Jurist-Diction
}

Volume 4 No. 6 November 202

\section{Keabsahan Hubungan Kerja Antara Perusahaan E-Sports Dengan Atlet $\boldsymbol{E}$-Sports Dibawah Umur}

\author{
I Putu Setya Agung \\ putusetyaagung@gmail.com \\ Universitas Airlangga
}

How to cite:
I Putu Setya Agung 'Keabsahan
Hubungan Kerja Antara
Perusahaan E-Sports Dengan
Atlet E-Sports Dibawah Umur'
(2021) Vol. 4 No. 6 Jurist-
Diction.
Histori artikel:
Submit 6 April 2021 ;
Diterima 15 Oktober 2021 ;
Diterbitkan 5 November 2021.
DOI:
10.20473/jd.v4i6.31850
p-ISSN: 2721-8392
e-ISSN: 2655-8297
cc)(1)

\section{Abstract}

e-Sports is a new profitable industry at this time. Activists in this field consist of various groups, both adults and children. Underage e-sports athletes are the main target of e-sports companies to use their services in competing. Children who become e-Sports athletes are later called child labor. Author uses a type of juridical normative legal research with a statute approach, conceptual approach, and case studies. The validity of employment agreements and work relationships between child as e-Sports athletes and e-Sports companies must also include the role of the parent or guardian who has authority over the child. A legal work relationship is a work relationship that fulfills the elements of a work relationship, namely orders, jobs and wages. If a work relationship does not fulfill only one element, it cannot be called an work relationship. The work relationship that exists between underage e-sports athletes and e-sports companies is legal.

Keywords: E-Sports; Child Labor; Employment Agreement; Work Relationship; Legality.

\begin{abstract}
Abstrak
e-Sports merupakan industri baru yang cukup menjanjikan pada saat ini. Penggiat bidang ini terdiri dari berbagai kalangan, baik orang dewasa hingga anak-anak. Atlet e-Sports dibawah umur menjadi sasaran utama dari perusahaan e-Sports untuk menggunakan jasanya dalam berkompetisi. Anak yang menjadi atlet e-Sports ini lah yang kemudian disebut pekerja anak. Penulis menggunakan tipe penelitian hukum normatif yuridis dengan pendekatan perundang-undangan, pendekatan konseptual, dan studi kasus. Keabsahan perjanjian kerja dan hubungan kerja antara anak dibawah umur sebagai atlet e-Sports dengan perusahaan e-Sports harus turut menyertakan peran orang tua atau wali yang memiliki kuasa atas anak tersebut. Hubungan kerja yang sah adalah hubungan kerja yang memenuhi unsur hubungan kerja yakni perintah, pekerjaan, dan upah. Jika suatu hubungan kerja tidak memenuhi salah satu unsur saja, maka tidak dapat disebut dengan hubungan kerja. Hubungan kerja yang terjalin antara atlet e-Sports dibawah umur dengan perusahaan e-Sports adalah sah.

Kata Kunci: E-Sports; Pekerja Anak; Perjanjian Kerja; Hubungan Kerja; Keabsahan.
\end{abstract}




\section{Pendahuluan}

Dewasa ini olahraga elektronik semakin banyak digandrungi oleh banyak kalangan, baik dari anak-anak hingga dewasa. Olahraga elektronik juga memiliki banyak kejuaraan yang dapat diikuti, hal ini meningkatkan keikutsertaan para pengolahraga dalam kejuaraan e-Sports. Di bidang olahraga elektronik juga dikenal dengan adanya atlet atau olahragawan profesional yang mengikuti kejuaraan atau kompetisi secara rutin, sesuai dengan pengertian olahragawan yang termaktub dalam undang-undang sistem keolahragaan nasional. Berdasarkan ketentuan dalam UU Nomor 3 Tahun 2005 tentang Sistem Keolahragaan Nasional, ruang lingkup olahraga dibagi menjadi 3 yakni olahraga pendidikan, olahraga rekreasi dan olahraga prestasi. E-Sports dikategorikan sebagai olahraga prestasi yang dilakukan secara profesional karena memenuhi unsur-unsur yang ada yakni untuk meningkatkan kemampuan dan potensi olahragawan; dilakukan berdasarkan bakat, kemampuan, dan potensi demi meraih prestasi; dilaksanakan melalui pembinaan dan pengembangan yang didukung oleh teknologi keolahragaan; dan dilakukan untuk memperoleh pendapatan atas kemahiran berolahraganya. ${ }^{1}$ Maka dari itu e-Sports tergolong dalam olahraga profesional, karena penggiat e-Sports merupakan atlet atau olahragawan seperti yang dimaksud dalam peraturan perundang-undangan.

Industri e-Sports merupakan salah satu industri yang paling menghasilkan pundi-pundi materi. Di Indonesia memiliki memiliki hubungan baik antara industri e-Sports dan badan pemerintahan yakni Badan Ekonomi Kreatif (Bekraf). Hal ini terwujud dalam salah satu sesi talk show antara Direktur Infrastruktur TIK Badan Ekonomi Kreatif dengan beberapa pelaku $e$-Sports pada acara yang bertajuk IDByte Esports 2019 di BSD City, Kota Tangerang tertanggal 13 September 2019. Beliau berpendapat bahwa e-Sports sudah mendapat sorotan khusus dari KSP (Kantor Staf Presiden), dan telah memberikan siyalemen kuat agar alokasi sumber daya dan anggaran dapat dikerahkan pada ranah e-Sports, termasuk yang bersumber dari

${ }^{1}$ Dimas Hutomo, ‘Adakah Landasan Hukum E-Sports di Indonesia?' (hukumonline, 2018) $<$ www.hukumonline.com>, dikunjungi pada tanggal 1 September 2020. 
Bappenas. $^{2}$ Setahun sebelumya tepatnya pada tanggal 23 Desember 2018, Badan Ekonomi Kreatif melalui kepalanya yakni Triawan Munaf mengatakan bahwa benar Games merupakan salah satu dari 16 subsektor yang kini menjadi prioritas Bekraf. ${ }^{3}$ Hal ini pun berkesesuaian dengan fungsi Badan Ekonomi Kreatif yang tertuang dalam Peraturan Presiden Nomor 6 Tahun 2015 tentang Badan Ekonomi Kreatif juncto Peraturan Presiden Nomor 72 Tahun 2015 tentang Perubahan atas Peraturan Presiden Nomor 6 Tahun 2015 tentang Badan Ekonomi Kreatif.

Indonesia memiliki beberapa atlet e-Sports dari kalangan anak-anak yang prestasinya sudah tidak diragukan lagi baik di kompetisi tingkat nasional maupun internasional. Salah satu dari mereka adalah Profesional player cilik yang merupakan jawara game konsol Pro Evolution Soccer dari tim e-Sports ZEUS yakni Rizky Faidan yang meraih predikat runner-up di ajang Pro Evolution Soccer League World Finals 2019 yang diadakan di London, Inggris pada tahun 2019 lalu. ${ }^{4}$ Pada saat itu Rizky masih berusia 16 tahun dan berhasil meraih prestasi yang membanggakan dan mengharumkan nama Indonesia di kancah Internasional. Selain Rizky Faidan yang menjadi jawara dari kejuaraan game Pro Evolution Soccer yang merupakan game konsol, terdapat juga jawara cilik yang menggeluti $e$-Sports melalui perangkat mobile (smartphone), mereka adalah si kembar Made Bagus dan Made Bagas yang merupakan andalan tim Bigetron e-Sports untuk divisi game Player Unkown's Battleground Mobile atau biasa disebut PUBG Mobile. Prestasi yang ditorehkan oleh duet fenomenal ini sangat luar biasa untuk usianya yang masih terbilang sangat muda. Kejuaraan tingkat nasional dan internasional sudah mereka rasakan dan keluar sebagai juara. Dilansir dari suatu website portal berita, si kembar Made

${ }^{2}$ Chandrataruna, 'Bekraf Buka-bukaan Soal e-Sports di Indonesia', (skygrid, 2019) $<$ https:// media.skyegrid.id/bekraf-buka-bukaan-soal-esport-di-indonesia/>, dikunjungi pada 10 Oktober 2020.

3 Nugyasa Laksamana, 'Besarnya Peluang Usaha dan Profesi Dunia e-Sports di Indonesia' (kompas, 2018) <https://bola.kompas.com/read/2018/12/23/18450078/besarnya-peluang-usahadan-profesi-dunia-e-Sports-di-indonesia?page=all $>$, dikunjungi pada 10 Oktober 2020 .

${ }^{4}$ Hanif Sri Yulianto, 'Indonesia Raih Peringkat Kedua PES League World Finals 2019', (Bola, 2019) <https://www.bola.com/e-Sports/read/4002238/indonesia-raih-peringkat-kedua-pes-league-world-finals-2019\#: :text=Indonesia\%20Raih\%20Peringkat $\% 20 \mathrm{Kedua} \% 20$ PES\%20League\%20World\%20Finals\%202019,-Hanif\%20Sri\%20Yulianto\&text=Rizky\%20 Faidan\%20tersisih\%20pada\%20fase,juara\%20dunia\%20sebanyak\%20dua\%20kali>, diakses pada 9 September 2020. 
Bagus dan Made Bagas telah meraih prestasi di kancah internasional sekaligus mengharumkan nama bangsa, yakni menjadi juara 1 turnamen PUBG Mobile Club Open (PMCO) Fall Split Global Finals pada tahun 2019. Turnamen ini diadakan di Putra Trade World Centre, Kuala Lumpur Malaysia. ${ }^{5}$ Perlu diketahui juga duo Made ini kelahiran tahun 2003, dengan kata lain pada saat meraih prestasi luar biasa di atas mereka masih berusia 16 tahun. ${ }^{6}$

Dua kasus di atas menjadi bukti bahwa telah meluasnya industri e-Sports hingga menjangkau kalangan anak-anak terlebih dari segi game online. Tingginya minat dan potensi pemain game yang berasal dari kalangan anak-anak juga menjadi faktor ketertarikan dari perusahaan e-Sports untuk melakukan pembinaan pada anak-anak yang sekiranya memiliki potensi ini. Tak hanya sekedar pembinaan dan bimbingan saja yang dilakukan oleh perusahaan penggiat e-Sports melainkan merekrut anak-anak muda potensial ini untuk menjadi atlet professional dan menjadi aset bagi perusahaan di masa kini dan masa yang akan datang.

Pemain game profesional yang sudah digaet oleh perusahaan e-Sports telah berubah status menjadi atlet $e$-Sports karena dengan bergabungnya pemain game profesional tersebut, pemain game yang bersangkutan akan secara rutin mengikuti pelatihan, pembinaan, hingga kompetisi yang telah disepakati oleh atlet dengan perusahaan. Bentuk nota kesepakatan yang lazim untuk atlet adalah kontrak kerja dan berpedoman dengan Undang-Undang Nomor 13 Tahun 2003 tentang Ketenagakerjaan. Atlet dibawah umur memiliki perbedaan dalam melaksanakan perjanjian/kontrak kerja dibandingkan dengan atlet yang sudah dewasa. Kemudian bagaimana keabsahan perjanjian kerja atlet e-Sports dibawah umur sesuai dengan ketentuan mengenai pekerja anak yang tertuang pada Undang-Undang

\footnotetext{
${ }^{5}$ Yuslianson, 'Bigetron RA Juarai PMCO Fall Split Global Finals 2019, Kantongi Rp 2,8 Miliar' (Liputan 6, 2019) <https:/www.liputan6.com/tekno/read/4124063/bigetron-ra-juaraipmco-fall-split-global-finals-2019-kantongi-rp-28-miliar\#: :text=Game-,Bigetron\%20RA\%20 Juarai\%20PMCO\%20Fall\%20Split\%20Global\%20Finals,Kantongi\%20Rp\%202\%2C8\%20 Miliar\&text=Liputan6.com\%2C\%20Jakarta\%20\%2D\%20Bigetron,Fall\%20Split\%20Global\%20 Finals\%202019.>, diakses pada 12 September 2020.

${ }^{6}$ Taufiq Bagaskara, 'Ini Dia Biodara dan Profil BTR Zuxxy Player dari Bigetron eSports' (Grid, 2019) <https:/games.grid.id/read/151777027/ini-dia-biodata-dan-profil-btr-zuxxy-playerdari-bigetron-esports?page=all $>$, dikunjungi pada 12 September 2020.
} 
Ketenagakerjaan? Hal ini menjadi penting untuk dibahas, terutama di tengah isu ramainya professional player cilik yang berstatus sebagai atlet $e$-Sports untuk suatu tim atau perusahaan e-Sports.

\section{Metode Penelitian}

Penulis menggunakan metode penelitian normatif-yuridis dengan pendekatan:

a) Pendekatan peraturan perundang-undangan (statute approach)

b) Pendekatan konseptual (conceptual approach)

c) Studi kasus

\section{Perjanjian Kerja dalam $e$-Sports}

\section{Perjanjian, Perjanjian Kerja dan Hubungan Kerja}

Perjanjian menurut R. Wirjono Projodikoro adalah suatu hubungan hukum mengenai harta benda antara dua pihak dimana satu pihak berjanji untuk melakukan suatu hal atau tidak melakukan suatu hal janji sedangkan pihak lain menuntut pelaksanaannya. ${ }^{7}$ Sedangkan menurut R. Subekti perjanjian merupakan suatu peristiwa hukum dimana seseorang berjanji kepada orang lain atau dimana dua orang itu saling berjanji untuk melaksanakan suatu hal. ${ }^{8}$ Selain itu K. R. M. T Tirtodiningrat juga turut menuangkan pemikirannya mengenai definisi perjanjian, menurut beliau perjanjian adalah suatu perbuatan hukum berdasarkan kata sepakat di antara dua orang atau lebih untuk menimbulkan akibat-akibat hukum yang dapat dipaksakan oleh undang-undang. ${ }^{9}$

Di atas merupakan makna atau definisi perjanjian menurut para ahli, jika berpacu pada peraturan perundang-undangan yakni Burgerlijk Wetboek (selanjutnya akan disebut BW) tepatnya pada Pasal 1313 BW mengemukakan bahwa perjanjian adalah suatu perbuatan dengan mana satu orang atau lebih mengikatkan dirinya

\footnotetext{
${ }^{7}$ Wirjono Prodjodikoro, Asas-Asas Hukum Perjanjian (Sumur 1981).[9].

${ }^{8}$ R Subekti, Hukum Perjanjian (Intermasa 1987).[1].

${ }^{9}$ A. Qirom Meliala, Pokok-Pokok Hukum Perikatan Beserta Perkembangannya (Liberty 1985).[8].
} 
terhadap satu orang lain atau lebih. Namun beberapa ahli menyatakan ketentuan yang diatur dalam Pasal 1313 BW menimbulkan kerancuan dan dianggap maknanya terlalu luas. Pernyataan beberapa ahli tersebut antara lain:

a) R. M. Suryodiningrat, mengemukakan bahwa definisi yang tertuang dalam Pasal 1313 BW hanya mengenai persetujuan sepihak, yakni satu pihak saja yang berprestasi sedangkan pihak lainnya tidak berprestasi (misal: hibah) dan seharusnya persetujuan itu berdimensi dua pihak, dimana para pihak saling berprestasi. Kemudian Pasal 1313 BW hanya berkenaan dengan persetujuan obligatoir (melahirkan hak dan kewajiban bagi para pihak), dan tidak berlaku bagi persetujuan jenis lainnya (misal: perjanjian kebendaan, perjanjian liberatoir/pembebasan). ${ }^{10}$

b) Setiawan, berpendapat bahwa rumusan Pasal 1313 BW tidak lengkap dan bermakna sangat luas. Tidak lengkap karena hanya menyebutkan persetujuan sepihak saja, dan sangat luas karena terdapat kata "perbuatan" yang mana tercakup pula perwakilan sukarela dan perbuatan melawan hukum. Maka dari itu menurut Setiawan perlu kiranya diadakan perbaikan definisi dalam Pasal 1313 BW, yakni perbuatan harus diartikan sebagai perbuatan hukum yang bertujuan untuk menimbulkan akibat hukum. Kemudian menambah frasa "atau saling mengikatkan dirinya" dalam rumusan Pasal tersebut, sehingga akan berbunyi sebagai berikut: "perjanjian adalah perbuatan hukum, dimana satu orang atau lebih mengikatkan dirinya atau saling mengikatkan dirinya terhadap satu orang atau lebih".

Definisi perjanjian yang dikemukakan oleh para ahli tersebut bermaksud untuk melengkapi kekurangan definisi perjanjian berdasarkan Pasal 1313 BW.

Sejatinya pada dewasa ini timbul kerancuan dalam istilah kontrak dan perjanjian. Ada yang beranggapan kedua istilah di atas merupakan hal yang sama sekali berbeda, ada pula yang beranggapan kedua istilah tersebut merupakan hal yang sama. Menurut R. Subekti sendiri kedua istilah di atas adalah berbeda, istilah kontrak

\footnotetext{
${ }^{10}$ R.M. Suryodiningnrat, Asas-Asas Hukum Perikatan (Tarsito 1985).[72-74].
} 
memiliki makna yang lebih sempit dibandingkan dengan istilah perjanjian karena kontrak ditujukan pada perjanjian dalam bentuk tertulis. ${ }^{11}$ Begitu Pula dengan Peter Mahmud Marzuki yang mengemukakan bahwa melalui konsep Anglo-American, perjanjian memiliki pengertian yang lebih luas dari kontrak. Dan perjanjian yang berkaitan dengan bisnis disebut dengan kontrak, sedangkan untuk perjanjian yang tidak berkaitan dengan bisnis hanya disebut perjanjian (agreement). ${ }^{12}$ Sedangkan menurut Agus Yudha Hernoko, menyatakan bahwa antara istilah kontrak dengan perjanjian adalah sama, karena beliau berfokus pada landasan perspektif BW, yakni perjanjian dan kontrak memiliki pengertian yang sama. ${ }^{13}$

Berbicara mengenai perjanjian tentu erat kaitannya dengan syarat sahnya perjanjian, karena syarat sahnya perjanjian merupakan tulang punggung dari suatu keabsahan perjanjian. Syarat sahnya perjanjian diatur dalam Pasal 1320 BW, yakni:

a) Sepakat bagi mereka yang mengikatkan dirinya (de toesteming van degenen die zich verbinden);

Dalam mencapai kata sepakat terdapat unsur penawaran dan penerimaan. Pada hakikatnya kata sepakat terjadi setelah adanya persesuaian antara penawaran dan penerimaan (pertemuan antara dua kehendak) ${ }^{14}$

b) Kecakapan untuk membuat suatu perikatan (de bekwaamheid om eene verbintes aan te gaan);

Kecakapan atau kemampuan para pihak dalam melakukan perbuatan hukum ditandai dengan kedewasaan seseorang. Orang yang dirasa telah cakap adalah orang dewasa yakni berusia 21 (dua puluh satu) tahun atau sudah menikah. Sedangkan orang yand tidak cakap dan tidak diperbolehkan melakukan suatu perbuatan hukum, berdasarkan Pasal 1330 BW adalah:

1. Anak dibawah umur;

2. Orang yang berada dalam pengampuan;

3. Perempuan dalam hal-hal yang ditetapkan oleh undang-undang telah melarang membuat perjanjian tertentu.

c) Suatu hal tertentu (een bepaald onderwerp);

Hal tertentu yang dimaksud adalah suatu prestasi yang menjadi pokok dalam perjanjian, sehingga prestasi ini lah yang memastikan sifat dan luasnya

\footnotetext{
${ }^{11}$ R. Subekti, Op.Cit.[1].

${ }^{12}$ Peter Mahmud Marzuki, 'Batas-Batas Kebebasan Berkontrak' (2003) Vol. 18 No. 3 Yuridika.[195-196].

${ }^{13}$ Agus Yudha Hernoko, Hukum Perjanjian (Kencana 2010).[15].

${ }^{14}$ Muhammad Teguh Pangestu, Pokok-Pokok Hukum Kontrak (Social Politic Genius 2019). [98].
} 
pernyataan yang menjadi hak dan kewajiban para pihak (kreditor dan debitor); ${ }^{15}$

d) Suatu sebab yang halal (eene geoorloofde oorzaak);

Perjanjian memerlukan adanya sebab yang halal, yang mana terdapat sebabsebab hukum yang menjadi alas perjanjian yang tidak dilarang oleh peraturan, keamanan dan ketertiban umum dan sebagainya. ${ }^{16}$

Dalam BW juga diatur mengenai perjanjian kerja tepatnya pada Pasal 1601 BW, ketentuan ini mengemukakan bahwa perjanjian kerja adalah suatu perjanjian dimana pihak yang satu yakni buruh, mengikatkan diri untuk bekerja pada pihak yang lain yaitu majikan, selama suatu waktu tertentu dengan menerima upah. Para ahli juga mengemukakan pemikirannya mengenai perjanjian kerja. Menurut Imam Soepomo, perjanjian kerja merupakan suatu perjanjian dimana pihak yang satu, buruh, mengikatkan diri untuk bekerja pada pihak yang lain yakni majikan, selama suatu waktu tertentu dengan menerima upah dan dimana pihak yang lain, majikan, mengikatkan diri untuk mempekerjakan pihak yang satu, buruh, dengan membayar upah. Suatu perjanjian kerja dianggap sah tidak terlepas dari syarat sahnya perjanjian yang tertuang pada Pasal $1320 \mathrm{BW}$ dan telah penulis kemukakan diatas.

Berdasarkan Pasal 1 angka 14 Undang-Undang Ketenagakerjaan, perjanjian kerja adalah perjanjian antara pekerja/buruh dengan pengusaha atau pemberi kerja yang memuat syarat-syarat kerja, hak, dan kewajiban para pihak. Perjanjian kerja dibentuk oleh pekerja/buruh dan pengusaha (pemberi kerja) berdasarkan kesepakatan-kesepakatan yang tercapai oleh keduabelah pihak. Dari perjanjian kerja ini lah timbul suatu hubungan hukum antara pekerja dan pemberi kerja yakni hubungan kerja.

Hubungan kerja memiliki peran esensial dalam Hukum Perburuhan. Hubungan kerja memiliki konsep sub-ordinasi atau hubungan yang membentuk tingkatan (hirarki). Pada hakikatnya, hubungan kerja merupakan hubungan antara buruh dan majikan yang terbentuk setelah diadakannya perjanjian antara buruh dan pemberi kerja, Berdasarkan Pasal 50 Undang-Undang Ketenagakerjaan hubungan kerja terjadi karena adanya perjanjian kerja antara pengusaha dan pekerja/buruh.

\footnotetext{
${ }^{15}$ ibid.

${ }^{16}$ ibid.[97].
} 
Buruh memberi kesanggupan untuk bekerja pada majikan (pemberi kerja) dengan menerima imbalan berupa upah, sedangkan majikan (pemberi kerja) menyatakan kesanggupan untuk mempekerjakan buruh dengan membayar upah. Menurut Pasal 1 angka 15 hubungan kerja adalah hubungan antara pengusaha dengan pekerja/ buruh berdasarkan perjanjian kerja, yang memiliki unsur pekerjaan, upah, dan perintah. Unsur-unsur dalam hubungan kerja dijabarkan sebagai berikut:

a) Pekerjaan

Sejatinya dalam Undang-Undang Nomor 13 Tahun 2003 tentang Ketenagakerjaan (selanjutnya akan disebut Undang-Undang Ketenagakerjaan) tidak mendefinisikan secara terang mengeai pekerjaan, namun menurut Kartasapoetra, pekerjaan atau bekerja adalah pengerahan tenaga kerja atas jasa seseorang yang telah terikat oleh suatu perjanjian dengan orang lain dengan tunduk kepada perintah-perintah dan kepentingan orang lain tersebut, dengan maksud memperoleh imbalan atau upah. ${ }^{17}$

b) Perintah

Perintah merupakan petunjuk atau kehendak yang diinginkan oleh pengusaha (pemberi kerja), dapat berupa lisan dan/atau tertulis serta bermanfaat bagi pengusaha (pemberi kerja)

c) Upah

Berdasarkan Pasal 1 angka 30 Undang-Undang Ketenagakerjaan upah adalah hak pekerja/buruh yang diterima dan dinyatakan dalam bentuk uang sebagai imbalan dari pengusaha atau pemberi kerja kepada pekerja/buruh yang ditetapkan dan dibayarkan menurut suatu perjanjian kerja, kesepakatan, atau perundang-undangan, terasuk tunjangan bagi pekerja/buruh dan keluarganya atas suatu pekerjaan dan/atau jasa yang telah atau akan dilakukan.

Adapun beberapa hal yang mendasari hubungan kerja adalah sebagai berikut:

a) Perjanjian Kerja

Menurut Pasal 1 angka 14 Undang-Undang Ketenagakerjaan perjanjian kerja

${ }^{17}$ Kertasapoetra, G. et.al., Hukum Perburuhan Bidang Hubungan Kerja. (Armico 1990).[17]. 
adalah suatu perjanjian antara pekerja dan pengusaha atau pemberi kerja yang memuat syarat-syarat kerja, hak dan kewajiban kedua belah pihak. Perjanjian kerja dapat berbentuk lisan antara pekerja dan pengusaha atau tertulis melalui surat perjanjian yang ditandatangani oleh kedua belah pihak. Sesuai dengan ketentuan dalam Pasal 52 ayat (1) Undang-Undang Ketenagakerjaan perjanjian kerja dibuat berdasarkan pada:

1. Kesepakatan kedua belah pihak;

2. Kemampuan atau kecakapan melakukan perbuatan hukum;

3. Adanya pekerjaan yang diperjanjikan;

4. Pekerjaan yang diperjanjikan tidak bertentangan dengan ketertiban umum, kesusilaan, dan peraturan perundang-undangan yang berlaku.

Hal ini pun selaras dengan syarat sah nya perjanjian sesuai dengan Pasal 1320

BW seperti yang telah penulis paparkan diatas. Berdasarkan Pasal 56 ayat (1)

Undang-Undang Ketenagakerjaan perjanjian kerja memiliki 2 jenis, yaitu:

\section{Perjanjian Kerja Waktu Tertentu (PKWT)}

Biasa juga disebut dengan perjanjian kerja kontrak yang dibuat berdasarkan waktu tertentu atau berdasarkan selesainya pekerjaan tertentu, sehingga buruh yang bekerja dibatasi oleh waktu dalam bekerja. Suuatu PKWT wajib dibuat secara tertulis dan didaftarkan pada Dinas Ketenagakerjaan (Disnaker)

2. Perjanjian Kerja Waktu Tidak Tertentu (PKWTT)

Merupakan suatu perjanjian kerja yang waktunya tidak ditentukan, bersifat tetap dan terus menerus serta berlaku hingga terjadinya Pemutusan Hubungan Kerja (PHK). PKWTT dapat dibuat secara lisan.

b) Peraturan Perusahaan

Merupakan suatu peraturan secara tertulis yang dibuat oleh perusahaan atau pemberi kerja yang memuat syarat kerja dan tata tertib perusahaan dengan kondisi wakil pekerja di perusahaan sebagai pertimbangan pembentukan peraturan perusahaan ini. Peraturan Perusahaan wajib dibentuk oleh perusahaan yang mempekerjakan buruh sekurang-kurangnya 10 (sepuluh) orang, hal ini sesuai dengan ketentuan Pasal 108 Undang-Undang Ketenagakerjaan. Dalam peraturan perusahaan harus mengatur tentang: 
1. Hak dan kewajiban pekerja;

2. Syarat kerja;

3. Tata tertib perusahaan;

4. Jangka waktu berlakunya peraturan perusahaan.

Pada masa berlaku peraturan perusahaan jika terdapat keadaan serikat pekerja dalam perusahaan menginginkan diadakan perjanjian kerja Bersama, maka pihak perusahaan wajib untuk memenuhinya.

c) Perjanjian Kerja Bersama

Perjanjian kerja bersama merupakan perjanjian kerja hasil perundingan dengan musyawarah untuk mufakat antara serikat pekerja dan/atau beberapa serikat pekerja yang tercatat pada instansi yang berkepentingan di bidang ketenagakerjaan (Departemen Ketenagakerjaan) dengan pengusaha atau perkumpulan pengusaha yang memuat syarat kerja, hak, dan kewajiban kedua belah pihak.

\section{Perjanjian Kerja Atlet e-Sports}

Seperti yang telah dikemukakan diatas bahwa landasan yang mendasari hubungan kerja adalah adanya perjanjian kerja. Hubungan kerja muncul setelah substansi perjanjian kerja telah disepakati oleh kedua belah pihak yaitu pengusaha dan pekerja. Dalam perjanjian kerja atlet $e$-Sports yang menyepakati perjanjian ini adalah pengusaha dan atlet $e$-Sports sendiri. Perjanjian kerja yang dibuat untuk atlet e-Sports umumnya dibuat dalam bentuk tertulis. Isi yang termuat dalam perjanjian kerja antara pengusaha dan atlet e-Sports antara lain hak dan kewajiban, atlet e-Sports dan pengusaha, jam kerja atau jam latihan, jam latihan, pembayaran upah, dan penyelesaian sengketa.

Dalam Undang-Undang Ketenagakerjaan sendiri mengatur hal-hal yang harus dimuat dalam perjanjian kerja, tepatnya pada Pasal 54 ayat (1), yang mengemukakan bahwa perjanjian kerja yang dibuat secara tertulis sekurang-kurangnya memuat:

a. nama, alamat perusahaan, dan jenis usaha;

b. nama, jenis kelamin, umur, dan alamat pekerja/buruh;

c. jabatan atau jenis pekerjaan;

d. tempat pekerjaan;

e. besarnya upah dan cara pembayarannya;

f. syarat syarat kerja yang memuat hak dan kewajiban pengusaha dan pekerja/ 
buruh;

g. mulai dan jangka waktu berlakunya perjanjian kerja;

h. tempat dan tanggal perjanjian kerja dibuat; dan

i. tanda tangan para pihak dalam perjanjian kerja.

Namun tidak menutup kemungkinan apabila terdapat klausula lain yang tidak tercantum pada ketentuan Pasal 51 ayat (1) Undang-Undang Ketenagakerjaan selama hal-hal tersebut disepakati oleh para pihak dan tidak bertentangan dengan ketentuan peraturan perundang-undangan yang berlaku. Terkait upah dan hak serta kewajiban para pihak pengaturan dalam perjanjian kerja tidak boleh bertentangan dengan peraturan perusahaan, perjanjian kerja bersama, dan perundang-undangan yang berlaku. Agar kedua belah pihak memiliki legalitas dan kekuatan hukum yang sama atas hubungan kerja yang terjadi maka perjanjian kerja di atas dibuat sekurangkurangnya dua rangkap masing-masing bagi pengusaha dan pekerja dalam hal ini atlet $e$-Sports.

Jenis perjanjian kerja yang terbentuk antara penrusahaan e-Sports dan atlet e-Sports adalah perjanjian kerja waktu tertentu (PKWT) atau biasa disebut dengan pekerja kontrak, yang memungkinkan para atlet e-Sports dapat melanjutkan kontrak tersebut atau mengakhiri masa kerjanya. Hal ini disebabkan karena pekerjaan yang dilakukan oleh atlet $e$-Sports adalah bersifat sementara. ${ }^{18}$

Masuknya pemain $e$-Sports pada perusahaan $e$-Sports pada umumnya terdapat dua cara yakni yang pertama adalah merekrut gamer profesional yang belum pernah dikontrak oleh perusahaan e-Sports, dan kedua adalah dengan cara transfer pemain yakni perpindahan pemain dari perusahaan e-Sports satu ke perusahaan e-Sports yang lain dengan cara "membeli" pemain, sama hal nya dengan transfer dalam olahraga sepak bola.

Regulasi dalam bursa transfer atlet e-Sports berbeda tiap games, jadi tergantung dari divisi game apa atlet-atlet ini akan dipindahkan/ditransfer. Seperti contohnya dalam game League of Legends, game ini memiliki peraturan yang cukup ketat mengenai transfer atlet $e$-Sports. Dan perlu diketahui peran pengembang permainan

${ }^{18}$ Nila Vania, Hubungan Kerja Antara Atlit E-Sports Dengan Pengusaha CV Pemberi Kerja (2018) Skripsi pada Program Sarjana Universitas Airlangga Surabaya.[48]. 
(developer games) League of Legends juga turut ikut andil dalam hal bursa transfer atlet, League of Legends dinaungi oleh Riot Games selaku developernya. Regulasi yang dibentuk oleh Riot Games bersifat internasional karena liga games League of Legends diadakan di berbagai penjuru dunia. Sehingga dengan berlakunya regulasi ini, maka kontrak antara perusahaan e-Sports dan tim memiliki standar tersendiri. ${ }^{19}$

Dalam regulasi transfer yang ditetapkan oleh Riot Games menentukan bahwa pemain dilarang untuk mendorong pemain lain untuk pindah ke tim lain (dalam hal ini perusahaan e-Sports lain). Hal ini dilakukan untuk menghindari adanya transfer yang dilakukan pada tengah musim atau saat musim sedang berlangsung. Waktu transfer saat jendela transfer dibuka tergolong singkat, biasanya setelah musim diakhiri dan akan memulai musim baru, barulah jendela transfer ini dibuka. Maka dari itu pelatih atau manajer tim e-Sports akan berdiskusi terlebih dahulu sebelum membidik atlet yang menjadi target transfer. Selain diskusi internal dalam tim e-Sports para petinggi perusahaan e-Sports juga akan berdiskusi dengan perwakilan perusahaan e-Sports yang akan atletnya dipindahkan. ${ }^{20}$ Tentu pembicaraan ini tidak dilaksanakan di tengah-tengah musim sedang bergulir melainkan setelah musim berakhir dan membahas untuk jendela transfer yang akan dibuka. Dan diskusi antara petinggi perusahaan dan pemain yang akan dibidik perlu dilakukan dan tetap dilaksanakan setelah berakhirnya musim.

\section{Hubungan Kerja antara atlet $\boldsymbol{e}$-Sports dengan Perusahaan}

\section{Para Pihak dalam Hubungan Kerja Atlet e-Sports dan Perusahaan}

Diatas telah dijelaskan bahwa hubungan kerja timbul dari adanya perjanjian kerja. Dalam hubungan kerja tentu tak terlepas dari adanya para pihak yang terlibat dalam hubungan kerja tersebut. Pada umumnya secara sempit hubungan kerja melibatkan pekerja/buruh dan pengusaha/pemberi kerja, namun jika secara luas

\footnotetext{
${ }^{19}$ Ellavie Ichlasa Amalia, 'Seperti Apa Kondisi Bursa Transfer dan Kontrak Pemain e-Sports?', (Hybrid, 2020) < https://hybrid.co.id/post/seperti-apa-kondisi-bursa-transfer-dan-kontrak-pemain-esports $>$ dikunjungi pada 10 Oktober 2020.

${ }^{20}$ ibid.
} 
meninjau hukum perburuhan tak sebatas pada pekerja/buruh dengan pengusaha/ perusahaan saja melainkan ada pula pihak lain yang terlibat yakni serikat pekerja/ buruh, perkumpulan pengusaha serta pemerintah/penguasa. ${ }^{21}$

Para pihak yang terlibat secara langsung pada hubungan kerja pada pokoknya antara lain: Pertama, yakni pekerja/buruh. Makna pekerja/buruh pada hakikatnya adalah tiap orang yang melakukan pekerjaan dengan menerima upah atau imbalan dalam bentuk lain. Ada pula definisi mengenai tenaga kerja, menurut Darza Z. A. tenaga kerja adalah bagian dari penduduk usia kerja yang secara fisik dan mental mampu melakukan pekerjaan baik di dalam maupun di luar hubungan kerja guna menghasilkan barang atau jasa untuk memenuhi kebutuhan masyarakat. ${ }^{22}$ Hal yang menarik dalam kutipan diatas adalah adanya seseorang yang bekerja namun di luar hubungan kerja, yang mana berarti orang yang bersangkutan bekerja namun atas dirinya sendiri dan bukan bekerja untuk orang lain yang terikat pada suatu hubungan kerja. Contoh pekerja yang melakukan pekerjaan di luar hubungan kerja pada umumnya dapat kita temui pada pekerjaan di sektor informal seperti ojek, nelayan, penjahit, dan lain sebagainya. Sehingga dengan para pekerja yang bekerja diluar hubungan kerja, mereka tidak terikat pada kedudukan yang bersifat sub-ordinasi.

Kembali pada pekerja yang terlibat dalam hubungan kerja, pada dasarnya dalam Undang-Undang Ketenagakerjaan sendiri telah mendefinisikan pekerja, tepatnya pada Pasal 1 angka 3. Menurut Undang-Undang Ketenagakerjaan pekerja/buruh adalah setiap orang yang bekerja dengan menerima upah atau imbalan dalam bentuk lain. Pekerja/buruh melaksanakan pekerjaan dalam hubungan kerja berada dibawah perintah pihak lain dalam hal ini adalah majikan. Kemudian inilah yang menandakan bahwa hubungan kerja memiliki kedudukan yang bersifat sub-ordinasi. ${ }^{23}$

\footnotetext{
${ }^{21}$ Maimun, Hukum Ketenagakerjaan Suatu Pengantar (Pradnya Paramita 2007).[11]

${ }^{22}$ Darza Z. A., Kamus Istilah Bidang Ketenagakerjaan (Delima Baru 2000).[114].

${ }^{23}$ Wiwoho Sudjono, Persetudjuan Perburuhan (Yayasan Badan Penerbit Gadjah Mada Yogyakarta 1970).[7].
} 
Pihak kedua adalah pengusaha atau seringkali disebut dengan majikan. Pengusaha sejatinya merupakan seorang yang memiliki kendali atas pekerja/buruh yang dipekerjakan dan tentu dengan memperhatikan hak serta kewajiban baik dari pengusaha maupun perja/buruh itu sendiri. Menurut Pasal 1 angka 5 UndangUndang Ketenagakerjaan pengusaha meliputi:

a) orang perseorangan, persekutuan, atau badan hukum yang menjalankan suatu perusahaan milik sendiri;

b) orang perseorangan, persekutuan, atau badan hukum yang secara berdiri sendiri menjalankan perusahaan bukan miliknya;

c) orang perseorangan, persekutuan, atau badan hukum yang berada di Indonesia mewakili perusahaan sebagaimana dimaksud dalam huruf a dan $b$ yang berkedudukan di luar wilayah Indonesia.

Berdasarkan ketentuan di atas dapat diketahui bahwa pengusaha disini tidak selalu hanya orang perseorangan, melainkan dapat pula berbentuk peresekutuan (maatschap/vennootschap) serta badan hukum. Hal ini tidak seperti makna pengusaha secara umum yang telah diketahui pada masyarakat luas, yakni setiap orang yang melakukan atau menjalankan suatu usaha dengan tujuan memperoleh keuntungan dari aktivitas usahanya, dan menanggung segala risiko bisnis yang tengah dijalankannya. ${ }^{24}$ Hal ini tentu menanamkan mindset yang sedikit kurang tepat pada masyarakat bahwa pengusaha selalu orang perseorangan.

Selanjutnya adalah perusahaan, berdasarkan Pasal 1 angka 6 Undang-Undang Ketenagakerjaan perusahaan adalah:

a) setiap bentuk usaha yang berbadan hukum atau tidak, milik orang perseorangan, milik persekutuan, atau milik badan hukum, baik milik swasta maupun milik negara yang mempekerjakan pekerja/buruh dengan membayar upah atau imbalan dalam bentuk lain;

b) usaha-usaha sosial dan usaha-usaha lain yang mempunyai pengurus dan

\footnotetext{
${ }^{24}$ Hariyanto, 'Inilah Pengertian Pengusaha dan Bedanya dengan Wirausaha', (Ajaib, 2019) $<$ https://ajaib.co.id/inilah-pengertian-pengusaha-dan-bedanya-dengan-wirausaha/ $>$, dikunjungi pada 14 Oktober 2020.
} 
mempekerjakan orang lain dengan membayar upah atau imbalan dalam bentuk lain.

Perusahaan merupakan suatu tempat untuk melakukan proses produksi barang dan/atau jasa serta perusahaan adalah bagian teknik yang berupa pelaksanaan kegiatan proses produksi dan merupakan alat bagi usaha untuk menghasilkan keuntungan. ${ }^{25}$ Dari ketentuan Pasal 1 angka 6 Undang-Undang Ketenagakerjaan diatas diketahui bahwa badan usaha memiliki dua jenis, yang pertama badan usaha berbentuk badan hukum dan yang kedua badan usaha bukan badan hukum. Badan usaha berbadan hukum adalah wadah usaha yang memiliki harta kekayaan sendiri, dan dengan harta kekayaannya itulah badan hukum dapat melakukan perbuatan hukum sendiri, sekaligus bertanggung jawab sendiri dalam rangka mencapai tujuannya. ${ }^{26}$ Hal ini berkaitan dengan eksistensi badan hukum (rechtpersoon) sebagai subyek hukum selain orang perseorangan (natuurlijke person). Contoh badan usaha berbentuk badan hukum adalah Perseroan Terbatas, Koperasi, Yayasan.

Sedangkan badan usaha bukan badan hukum adalah badan usaha yang tidak termasuk dalam subjek hukum, melainkan yang menjadi subjek hukum disini adalah pengurusnya baik perorangan atau kolektif. Karena pengurus disini yang menjadi subjek hukum, maka pertanggungjawabannya dibebankan pada tindakan pribadi maupun kolektif para pengurusnya. Dengan kata lain perbuatan yang dilakukan oleh badan usaha bukan badan hukum merupakan perbuatan pribadi pengurusnya, sehingga memilik konsekuensi segala akibat harus ditanggung secara pribadi. Jika perbuatannya bersifat kolektif maka pertanggungjawabannya bersifat tanggung menanggung atau tanggungjawab renteng. ${ }^{27}$ Badan usaha bukan badan hukum tidak memiliki harta kekayaannya sendiri melainkan pengurus bertanggungjawab secara pribadi maupun kolektif terhadap harta kekayaannya.

\footnotetext{
${ }^{25}$ Oemar Moechtar, Teknik Pembuatan Akta Badan Hukum dan Badan Usaha di Indonesia (Airlangga University Press 2019).[7].

${ }^{26}$ Tim Dosen Hukum Perseroan Fakultas Hukum Universitas Airlangga, Buku Ajar Hukum Perseroan (Fakultas Hukum Universitas Airlangga 2011).[3].

${ }^{27}$ Tim Dosen Hukum Dagang Fakultas Hukum Universitas Airlangga, Buku Ajar Hukum Dagang (Departemen Hukum Perdata Fakultas Hukum Universitas Airlangga 2011).[48].
} 
Contoh badan usaha bukan badan hukum adalah Commanditaire Vennootschap (CV) dan Firma (Fa).

Pada hubungan kerja atlet e-Sports dengan perusahaan pihak yang terlibat di dalamnya adalah atlet e-Sports (pekerja/buruh) itu sendiri dengan perusahaan e-Sports atau biasa yang disebut dengan tim e-Sports (perusahaan pemberi kerja). Atlet $e$-Sports sendiri tentu memiliki hak serta kewajiban setelah menandatangani perjanjian kerja dengan perusahaan e-Sports. Kewajiban atlet e-Sports adalah bekerja dalam hal ini yakni mengikuti latihan rutin dan mengikuti kompetisi. Kedua bentuk kewajiban dalam hal bekerja di atas merupakan kewajiban pokok bagi atlet e-Sports. Dalam menjalankan kewajibannya, atlet e-Sports tentu telah memiliki jadwal yang telah ditetapkan oleh perusahaan, baik itu tertuang secara langsung di perjanjian kerja maupun pada peraturan perusahaan. Para atlet e-Sports harus mengindahkan aturan yang ada mengenai jadwal latihan rutin, apabila tidak maka tak menutup kemungkinan atlet yang melanggar akan diberi teguran keras bahkan dikenai sanksi. Kemudian kewajiban selanjutnya adalah mengikuti kompetisi. Keikutsertaan atlet e-Sports dalam kompetisi e-Sports tentu merupakan hal yang esensial bagi keberlangsungan atlet e-Sports maupun perusahaan. Karena dengan mengikuti kompetisi, besar peluang bagi perusahaan untuk meraih profit. Sumber pemasukan terbesar adalah sponsorship dan hadiah kompetisi itu sendiri. Semakin hebat para atlet $e$-Sports beserta tim maka semakin gencar pula perusahaan lain yang berkeinginan untuk memberikan dana sponsor bagi perusahaan yang menaungi atlet-atlet e-Sports tersebut. Seperti contohnya perusahaan Bigetron e-Sports yang memiliki segudang prestasi melalui atlet $e$-Sports miliknya, yang telah berulang kali meraih juara baik dari kompetisi domestik dan internasional. Dengan kepercayaan atas prestasi-prestasi inilah yang membuat perusahaan raksasa asal Amerika Serikat yang fokus pada industri perangkat keras komputer yakni Corsair, menjadi sponsor dari perusahaan Bigetron e-Sports. ${ }^{28}$ Kemudian seperti yang sudah dijelaskan

\footnotetext{
${ }^{28}$ Yabes Elia, 'Antara Sponsor, Tim, dan Event e-Sports: Sebuah Pengantar' (Hybrid, 2018) $<$ https:/hybrid.co.id/post/antara-sponsor-tim-dan-event-esports-sebuah-pengantar $>$ dikunjungi pada 20 Oktober 2020.
} 
sebagai contoh di atas bahwa Bigetron e-Sports yang telah meraih banyak prestasi dari kompetisi e-Sports yang mereka ikuti tentu meraih banyak pemasukan dari hadiah kompetisi. Tercatat pada kompetisi PUBG Mobile Club Open Global Final 2019, Bigetron e-Sports melalui tim dari divisi PUBG Mobile bernamakan Bigetron Red Aliens berhasil menjuarai kompetisi tersebut dengan hadiah yang tak tanggungtanggung yakni sebesar US\$ 180.000,- atau seekitar Rp. 2,5 Milyar. ${ }^{29}$

Setelah kewajiban yang telah ditunaikan tentu atlet $e$-Sports juga memiliki hak. Hak yang paling mendasar dalam suatu hubungan kerja adalah upah. Berdasarkan Pasal 1 angka 30 Undang-Undang Ketenagakerjaan upah adalah hak pekerja/buruh yang diterima dan dinyatakan dalam bentuk uang sebagai imbalan dari pengusaha atau pemberi kerja kepada pekerja/buruh yang ditetapkan dan dibayarkan menurut suatu perjanjian kerja, kesepakatan, atau peraturan perundang undangan, termasuk tunjangan bagi pekerja/buruh dan keluarganya atas suatu pekerjaan dan/atau jasa yang telah atau akan dilakukan. Upah sendiri terdiri atas komponen: upah tanpa tunjangan; upah pokok dan tunjangan tetap; atau upah pokok, tunjangan tetap, dan tunjangan tidak tetap, hal ini berkesesuaian dengan Pasal 5 ayat (1) Peraturan Pemerintah Nomor 78 Tahun 2015 tentang Pengupahan. Dalam pengupahan dikenal dengan adanya upah minimum, berdasarkan Pasal 89 ayat (1) Undang-Undang Ketenagakerjaan upah minimum dapat terdiri atas upah minimum berdasarkan wilayah provinsi atau kabupaten/kota, dan upah minimum berdasarkan sektor pada wilayah provinsi atau kabupaten/kota. Atlet $e$-Sports sendiri rata-rata memiliki gaji di atas Upah Minimum Regional (UMR). Seperti yang diungkapkan oleh Andrian Pauline selaku CEO perusahaan e-Sports ternama Rex Regum Qeon (RRQ), bahwa gaji professional player secara umum kisarannya US\$ 300 hingga US\$ $6.000 .{ }^{30}$

${ }^{29}$ Dhiany Nadya Utami, 'Tim Bigetron RA Sabet Rp 2,5 Miliar, Bawa Indonesia Juara Dunia PUBG Mobile', (Bisnis 2019) <https://teknologi.bisnis.com/read/20191202/280/1176814/ tim-bigetron-ra-sabet-rp25-miliar-bawa-indonesia-juara-dunia-pubg-mobile\#: :text=Bigetron $\% 20$ mendapatkan\%20trofi\%20dan\%20hadiah,di\%20kompetisi\%20tingkat\%20Asia\%20Tenggara>, dikunjungi pada tanggal 25 Oktober 2020.

${ }^{30}$ Martini, 'CEO RRQ Bongkar Nominal Gaji Pro Player: Hampir Seratus Juta!', (Indosport 2020)<https://www.indosport.com/esports/20200517/ceo-rrq-bongkar-nominal-gaji-pro-player-hampir-seratus-juta $>$, dikunjungi pada tanggal 26 Oktober 2020. 
Merupakan upah yang terbilang sangat tinggi jika dikonversi dengan mata uang rupiah saat ini, yakni mencapai 80 juta rupiah per bulan. Jika ditinjau mengenai maksud dan tujuan pemberlakuan aturan upah minimum yang diarahkan pada pencapaian kebutuhan hidup yang layak, maka hak atlet $e$-Sports telah terpenuhi. Tak hanya pencapaian kehidupan yang layak yang terpenuhi bagi atlet $e$-Sports melainkan kesejahteraan pun juga tercapai.

Kemudian pihak yang kedua adalah perusahaan e-Sports, perusahaan $e$-Sports juga memiliki hak dan kewajiban. Kewajiban perusahaan e-Sports adalah mengembangkan bakat, minat, serta keterampilan atlet e-Sports melalui fasilitas yang diberikan bagi atlet $e$-Sports. Fasilitas yang dimaksud antara lain: perangkat dapat berupa smartphone atau personal computer tergantung dari divisi game apa sang atlet $e$-Sports tekuni, kemudian fasilitas lain yang diberikan oleh perusahaan e-Sports yakni transportasi, keamanan, kenyamanan, gaji pokok hingga biaya makan. ${ }^{31}$ Dalam melaksanakan kewajibannya tentu perusahaan e-Sports memiliki hak, yakni memberi perintah bagi atlet $e$-Sports untuk melaksanakan pekerjaannya yakni latihan dan berkompetisi seperti yang telah penulis kemukakan di atas. Dengan menuntut hak-hak tersebut perusahaan e-Sports juga menaruh harapan kepada para atletnya untuk selalu tekun mengasah keteramilan dalam bermain game serta menjuarai berbagai kompetisi. Karena dengan semakin sering suatu tim atau perusahaan e-Sports menjuarai kompetisi maka semakin besar nama perusahaan tersebut dan semakin besar pula profit yang diperoleh. Singkatnya dengan semakin rutin para atlet berlatih dan mengasah skill bermain game yang diperlombakan dalam e-Sports maka semakin hebat keterampilan atlet-atlet tersebut. Semakin hebat atlet tersebut semakin tinggi pula keuntungan yang diraup oleh perusahaan e-Sports baik dari kompetisi maupun sponsor.

Umumnya perusahaan e-Sports berbentuk CV. Seperti yang telah diuraikan di atas, Commanditaire Vennootschap (CV) merupakan badan usaha bukan badan

\footnotetext{
${ }^{31}$ Kibezaka, 'Pantau Berapa Gaji Pemain RRQ HoshiMobile Legends', (Kibezaka 2020) $<$ https://www.kibezaka.com/2020/04/pantau-berapa-gaji-pemain-rrq-hoshi.html $>$ dikunjungi pada tanggal 26 Oktober 2020.
} 
hukum, sehingga yang segala tindakan beserta akibatnya merupakan tanggung jawab orang-perseorangan pengurus $\mathrm{CV}$, jika tindakan dilakukan lebih dari satu orang maka akan tanggung menanggung atau tanggung jawab renteng. Dengan meninjau definisi pengusaha yang dimaksud dalam Pasal 1 angka 5 Undang-Undang Ketenagakerjaan yakni pengusaha termasuk orang perseorangan, persekutuan atau badan hukum yang menjalankan perusahaan milik sendiri, perusahaan milik orang lain, atau perusahaan yang berdisri di Indonesia untuk mewakili perusahaan yang berada di luar wilayah Indonesia. Sehingga dapat ditarik kesimpulan bahwa perusahaan e-Sports yang berbentuk $\mathrm{CV}$ atau yang disebut persekutuan komanditer termasuk dalam definisi "pengusaha” menurut Undang-Undang Ketenagakerjaan.

\section{Keabsahan Hubungan Kerja antara Atlet $e$-Sports dengan Perusahaan $e$-Sports}

Hubungan kerja memiliki 3 unsur penting berdasarkan Pasal 1 angka 15 Undang-Undang Ketenagakerjaan, yakni pekerjaan, upah, dan perintah. Untuk menguji keabsahan suatu hubungan kerja memang perlu ditinjau apakah ketiga unsur diatas telah terpenuhi atau tidak. Dalam beberapa literatur terdapat satu unsur yang tidak secara eksplisit diatur oleh undang-undang namun keberadaannya sangat penting dalam hubungan kerja, yakni waktu. ${ }^{32}$

Jika dibedah dari unsur per unsur maka didapati pengimplementasian per unsur dalam hubungan kerja antara atlet e-Sports dengan perusahaan e-Sports adalah sebagai berikut:

a) Pekerjaan

Dalam hubungan kerja atlet e-Sports dengan perusahaan e-Sports pekerjaan yang dimaksud adalah para atlet $e$-Sports mengikuti latihan rutin (bermain game) yang telah dijadwalkan oleh perusahaan serta ikut berkompetisi secara rutin pula, sehingga hal ini juga merupakan kewajiban yang harus dilaksanakan oleh atlet e-Sports. Tentu perlu diperhatikan pula bahwa pekerjaan yang dilakukan oleh atlet e-Sports yakni bermain game tidak bertentangan dengan peraturan perundang-undangan dengan kepentingan umum. Dengan bermain game maka pekerja (atlet e-Sports) telah menjalani kewajibannya sebagai pekerja dan perusahaan $e$-Sports telah memperoleh hak nya yakni memperoleh jasa untuk

\footnotetext{
${ }^{32}$ Nila Vania, Op.Cit.[35].
} 
bermain game dari atlet e-Sports.

b) Upah

Upah yang dimaksud adalah upah atau imbalan dalam bentuk lain yang diberikan oleh perusahaan e-Sports kepada atlet e-Sports. Umumnya bentuk upah yang diterima oleh atlet e-Sports adalah gaji pokok serta bonus setelah berhasil menjuarai suatu kompetisi. Sumber pemasukan perusahaan e-Sports seperti yang telah penulis terangkan di atas adalah dari adanya sponsor dan hadiah dari kompetisi. Dari sumber pemasukan itulah perusahaan e-Sports mengupah para atlet-atletnya. Perlu diketahui pula bahwa atlet e-Sports hanya menerima upah pokok tidak beserta tunjangan tetap maupun tunjangan tidak tetap, namun walaupun tak menerima tunjangan atlet $e$-Sports tetap menerima fasilitas yang layak dari perusahaan $e$-Sports seperti yang telah penulis jelaskan di atas. ${ }^{33}$

c) Perintah

Perusahaan e-Sports memiliki kewenangan untuk memberi perintah pada atlet e-Sports untuk melaksanakan pekerjaannya yakni melakukan latihan rutin dan berkompetisi. Perintah dan pekerjaan adalah hal yang selaras, dimana ada perintah sebagai hak dan kewenangan pengusaha maka ada kewajiban dari pekerja untuk melaksanakan pekerjaan yang telah diamanahkan bagi mereka dari suatu perintah tersebut. Ditambah dengan unsur upah yang merupakan hak dari pekerja.

d) Waktu

Dalam Pasal 1 angka 15 Undang-Undang Ketenagakerjaan memang tidak tertulis bahwa waktu (tjid) merupakan suatu unsur dari hubungan kerja, namun waktu merupakan hal yang sangat esensial dalam hubungan kerja. Waktu yang dimaksud adalah waktu hubungan kerja itu berlangsung. Pada sub bab sebelumnya telah dijelaskan bahwa atlet e-Sports merupakan pekerja dengan Perjanjia Kerja Waktu Tertentu (PKWT) sehingga waktu dalam hubungan kerja telah diatur dalam perjanjian kerja. Pekerjaan sebagai atlet e-Sports adalah bersifat tidak tetap maka dari itu perjanjian kerja yang berlaku adalah PKWT, dan PKWT dapat diperpanjang atau diperbaharui. PKWT dapat diadakan untuk paling lama 2 (dua) tahun. Dalam hal perpanjangan atau pembaruan kontrak atlet e-Sports seyogyanya berpedoman pada Undang-Undang Ketenagakerjaan yang menegaskan bahwa untuk perpanjangan kontrak hanya boleh diperpanjang 1 (satu) kali untuk jangka waktu paling lama 1 (satu) tahun. Dan untuk pembaruan kontrak hanya boleh dilakukan 1 (satu) kali dan paling lama 2 (dua) tahun.

Jika semua unsur yang telah penulis jabarkan di atas telah terpenuhi maka dapat disimpulkan bahwa hubungan kerja yang terjalin antara perusahaan $e$-Sports dengan atlet e-Sports adalah absah menurut hukum.

${ }^{33}$ ibid. [49]. 


\section{Keabsahan Hubungan Kerja antara Atlet e-Sports Dibawah Umur dengan Perusahaan}

\section{Kedudukan Para Pihak dalam Hubungan Kerja antara Atlet e-Sports dibawah umur dengan Perusahaan}

Hubungan kerja yang melibatkan anak sebagai pekerja tentu memiliki peraturan yang khusus dan berbeda dengan pekerja yang telah cakap berdasarkan usia untuk melaksanakan pekerjaan. Undang-Undang Ketenagakerjaan sendiri telah mengatur mengenai pekerja anak, tepatnya pada Bab X (ke-sepuluh), Bagian Kesatu, Paragraf kedua Undang-Undang Ketenagakerjaan. Sejatinya perusahaan dilarang mempekerjakan anak, namun ketentuan ini disimpangi oleh Pasal 69 ayat (1) Undang-Undang Ketenagakerjaan yang menegaskan bahwa bagi anak yang berumur antara 13 (tiga belas) tahun sampai dengan 15 (lima belas) tahun diperbolehkan untuk melakukan pekerjaan ringan sepanjang tidak mengganggu perkembangan dan kesehatan fisik, mental, dan sosial.

Persyaratan untuk mempekerjakan anak diatur dalam Pasal 69 ayat (2) Undang-Undang Ketenagakerjaan, syarat tersebut antara lain:

a) izin tertulis dari orang tua atau wali;

b) perjanjian kerja antara pengusaha dengan orang tua atau wali;

c) waktu kerja maksimum 3 (tiga) jam;

d) dilakukan pada siang hari dan tidak mengganggu waktu sekolah;

e) keselamatan dan kesehatan kerja;

f) adanya hubungan kerja yang jelas; dan

g) menerima upah sesuai dengan ketentuan yang berlaku.

Mengenai kedudukan para pihak yang terlibat dalam perjanjian kerja dan hubungan kerja antara anak dan perusahaan, terdapat pada 3 poin persyaratan di atas, yakni izin tertulis dari orang tua atau wali; perjanjian kerja antara pengusaha dengan orang tua atau wali; dan adanya hubungan kerja yang jelas. Dari ketiga poin persyaratan di atas telah jelas bahwa orang tua atau wali ikut terlibat dalam perjanjian kerja, yang mana perjanjian kerja yang telah dibuat melahirkan hubungan kerja antara anak yang bekerja dengan pengusaha.

Dalam hal atlet $e$-Sports dibawah umur sebagai pekerja anak maka penjabaran para pihak yang terlibat dalam perjanjian kerja dan hubungan kerja antara atlet 
e-Sports dengan perusahaan $e$-Sports adalah sebagai berikut:

a) Anak (atlet e-Sports dibawah umur)

Pekerja anak diposisikan sebagai pekerja yang juga memiliki hak dan kewajiban dalam sebuah hubungan kerja. Namun anak sejatinya tidak memiliki kecakapan dalam melakukan perbuatan hukum, seperti membuat dan secara langsung terlibat dalam perjanjian kerja. Dalam melaksanakan pekerjaannya, anak yang bekerja bersama-sama dengan pekerja dewasa harus dipisahkan tempat kerjanya dari tempat kerja pekerja dewasa. Selain itu anak tidak diperbolehkan dilibatkan pada pekerjaan-pekerjaan yang terburuk, seperti: pelacuran, pornografi, perjudian, terlibat dengan narkoba, dan pekerjaan lain yang membahayakan kesehatan, keselamatan, atau moral anak. Demikian pula dengan atlet e-Sports dibawah umur kewajiban serta hak-hak yang bersifat khusus harus terpenuhi dan harus terhindar dari pelanggaran hak-hak normatifnya.

b) Orang tua atau wali

Anak tidak memiliki kecakapan untuk membuat dan terlibat dalam perjanjian kerja secara langsung, maka dari itu peran orang tua atau wali sangat penting pada tahap ini. Orang tua atau wali dianggap sangat paham dengan kondisi, kemampuan, dan kesiapan anak sebelum melakukan pekerjaan, sehingga izin dari orang tua atau wali pekerja anak merupakan hal yang penting sebelum anak melakukan pekerjaannya. Dalam hal melaksanakan perjanjian kerja bukan anak yang terlibat secara langsung dalam perjanjian kerja antara pengusaha dengan anak, melainkan dengan orang tua atau wali. Kekuasaan orang tua atas anaknya untuk diatur dalam Undang-Undang Nomor 1 Tahun 1974 tentang Perkawinan, tepatnya pada Pasal 47 ayat (1) dan (2), yang mengemukakan bahwa:

1. Anak yang belum mencapai umur 18 (delapan belas) tahun atau belum pernah melangsungkan perkawinan ada dibawah kekuasaan orang tuanya selama mereka tidak dicabut dari kekuasaannya.

2. Orang tua mewakili anak tersebut mengenai segala perbuatan di dalam dan di luar Pengadilan.

Pada ketentuan Pasal 47 ayat (2) Undang-Undang Perkawinan telah sangat jelas 
menegaskan bahwa orang tua harus mewakili anak apapun perbuatan hukum yang dilakukan oleh anak baik didalam maupun di luar pengadilan, termasuk dalam hal melakukan perjanjian kerja. Selain orang tua terdapat pula anak yang dibawah perwalian, menurut Pasal 330 ayat (3) BW perwalian berlaku bagi mereka yang belum dewasa dan tidak berada dibawah kekuasaan orang tua. Tugas wali berdasarkan Pasal 383 ayat (1) BW adalah menyelenggarakan pemeliharaan dan pendidikan terhadap anak perwaliannya sesuai dengan harta kekayaannya dan wali harus mewakili anak dalam segala tindakan-tindakan. Maka dari itu wali turut memiliki kewenangan untuk mewakili anak selama si anak tidak berada dibawah kekuasaan orang tua. Perjanjian kerja antara orang yang belum dewasa dapat mengadakan perjanjian kerja dengan mendapat kuasa dari orang tua atau walinya. ${ }^{34}$ Dalam perjanjian kerja dan hubungan kerja antara atlet e-Sports dibawah umur dengan perusahaan e-Sports menekankan pula bahwa orang tua atau wali mewakili tindakan hukum yang dilakukan oleh atlet e-Sports dibawah umur terkhusus dalam perjanjian kerja, sekaligus melaksanakan pengawasan secara langsung terhadap hubungan kerja yang tengah berlangsung.

c) Perusahaan

Seperti yang telah dijelaskan pada sub bab sebelumnya, perusahaan bertindak sebagai pihak yang memberikan pekerjaan bagi pekerja. Dalam hal ini perusahaan mempekerjakan anak dan terdapat beberapa hal khusus yang harus diperhatikan sebelum perusahaan mempekerjakan anak. Hal yang dimaksud antara lain: tempat kerja bagi anak, waktu kerja, serta jenis pekerjaan yang akan atau sedang dilakukan oleh pekerja anak. Walaupun atlet e-Sports dibawah umur bekerja dengan "hanya" bermain game, yang mana sejatinya bermain game merupakan pekerjaan yang tergolong ringan dan mengasyikkan untuk dilaksanakan, namun perusahaan e-Sports harus tetap memberlakukan aturan-aturan yang sesuai dengan peraturan perundang-undangan agar tidak terjadi pelanggaran terhadap hak-hak normatif atlet e-Sports dibawah umur.

${ }^{34}$ Aloysius Uwiyono, dkk. Asas-Asas Hukum Perburuhan (RajaGrafindo Persada 2014).[66]. 
Jadi dapat disimpulkan bahwa terdapat perbedaan antara perjanjian perjanjian kerja atlet $e$-Sports biasa dengan perjanjian kerja atlet $e$-Sports dibawah umur dari aspek jumlah para pihak yang terlibat. Yakni perjanjian kerja atlet e-Sports yang telah cakap/cukup umur (diatas 18 tahun) pihak yang terlibat adalah atlet $e$-Sports yang bersangkutan dan perusahaan e-Sports, sedangkan perjanjian kerja atlet e-Sports dibawah umur (dibawah 18 tahun) pihak yang terlibat adalah atlet e-Sports yang bersangkutan, orang tua/wali, dan perusahaan e-Sports. Hal ini tak berlaku pada perjanjian kerja saja, melainkan pada hubungan kerja pula. Peran orang tua atau wali melakukan pengawsan secara langsung terhadap atlet $e$-Sports dibawah umur ini sebagai pekerja anak, sesuai dengan Pasal 71 ayat (2) huruf a UndangUndang Ketenagakerjaan.

\section{Keabsahan hubungan kerja atlet e-Sports dibawah umur dengan perusahaan e-Sports berdasarkan unsur-unsur hubungan kerja dan ketentuan khusus bagi pekerja anak menurut Undang-Undang Ketenagakerjaan}

Hubungan kerja atlet e-Sports dibawah umur dengan perusahaan e-Sports tetap berpedoman pada unsur-unsur hubungan kerja yang telah penulis jabarkan pada sub bab sebelumnya, yakni adanya unsur pekerjaan, upah, perintah, dan waktu. Namun perlu diingat bahwa pekerja anak menurut Undang-Undang Ketenagakerjaan memiliki ketentuan khusus dalam melaksanakan pekerjaannya. Penjabaran per unsur hubungan kerja adalah sebagai berikut:

a) Pekerjaan

Atlet e-Sports dibawah umur mungkin merasa senang apabila melakukan pekerjaannya yakni latihan rutin bermain game, namun beban sebagai professional player tetap dipikul oleh atlet e-Sports dibawah umur ini. Ketentuan khusus bagi pekerja anak tentu melekat pula pada atlet e-Sports dibawah umur. Berdasarkan Undang-Undang Ketenagakerjaan, perbandingan ketentuan bagi pekerja yang telah cakap secara usia dengan ketentuan khusus bagi pekerja anak dalam hal pekerjaan adalah sebagai berikut: 


\begin{tabular}{|c|c|c|}
\hline Ketentuan & Pekerja Dewasa & Pekerja Anak \\
\hline Waktu Kerja & $\begin{array}{l}7 \text { (tujuh) hingga } 8 \text { (dela- } \\
\text { pan) jam sehari }\end{array}$ & Maksimum 3 jam sehari \\
\hline Tempat Kerja & $\begin{array}{l}\text { Pekerja anak yang beker- } \\
\text { ja bersama-sama dengan } \\
\text { pekerja dewasa yang lain } \\
\text { tempat kerjanya tidak } \\
\text { dipisahkan }\end{array}$ & $\begin{array}{l}\text { Jika dipekerjakan bersama-sama dengan } \\
\text { pekerja dewasa, maka tempat kerja anak ha- } \\
\text { rus dipisahkan }\end{array}$ \\
\hline $\begin{array}{l}\text { Kondisi dan } \\
\text { lingkungan kerja }\end{array}$ & - & $\begin{array}{l}\text { Tidak mengganggu perkembangan fisik, } \\
\text { mental, sosial, dan waktu sekolah }\end{array}$ \\
\hline
\end{tabular}

b) Upah

Ketentuan mengenai upah bagi atlet e-Sports dibawah umur memang belum diatur secara khusus, namun berdasarkan Pasal 69 ayat (2) huruf g Undang-Undang Ketenagakerjaan mengemukakan bahwa pekerja anak menerima upah sesuai dengan ketentuan yang berlaku. Maka dari itu upah yang diterima oleh pekerja anak adalah sama dengan pekerja dewasa berpacu pada ketentuan upah minimum. Seperti yang telah penulis jelaskan pada sub bab sebelumnya, bahwa rata-rata upah atlet $e$-Sports sudah berada diatas UMR (Upah Minimum Regional) yang mana hal ini juga dirasakan oleh atlet e-Sports dibawah umur. Sehingga unsur upah dan upah sabeagai hak atlet $e$-Sports disini telah terpenuhi.

c) Perintah

Perusahaan e-Sports memiliki kewenangan dan hak untuk memberi perintah pada atlet e-Sports untuk melaksanakan pekerjaannya, yakni latihan rutin dan mengikuti kompetisi. Begitu pula pada atlet e-Sports dibawah umur, yang harus melaksanakan perintah untuk bekerja dengan latihan rutin dan mengikuti kompetisi tentu dengan ketentuan bekerja seperti yang telah penulis jabarkan diatas.

d) Waktu

Waktu hubungan kerja ditentukan dari jenis perjanjian kerja. Jenis perjanjian kerja atlet e-Sports adalah PKWT, begitu pula berlaku pada atlet e-Sports dibawah umur.Atlet e-Sports yang bersangkutan dikontrak oleh perusahaan e-Sports dan bekerja atas kontrak yang telah disepakati keduabelah pihak. Hubungan kerja selesai padaan saat kontrak telah habis, dan dapat diperpanjang sesuai dengan kesepakatan 
para pihak dan ketentuan perundang-undangan yang telah penulis jabarkan pada sub sub bab sebelumnya

Atlet e-Sports dan perusahaan e-Sports yang menjalankan dibawah umur yang telah melaksanakan hubungan kerja berdasarkan unsur-unsur hubungan kerja di atas maka dapat dikatakan bahwa hubungan kerja yang terjalin atas kedua belah pihak adalah absah menurut hukum.

\section{Kesimpulan}

Perjanjian kerja dan hubungan kerja merupakan satu kesatuan yang tak dapat terpisahkan, perjanjian kerja melahirkan suatu hubungan kerja. Tentu perjanjian kerja tetap berpedoman pada keabsahan perjanjian yang diatur dalam Pasal $1320 \mathrm{BW}$. Hubungan kerja memiliki 3 (tiga) unsur menurut Undang-Undang Ketenagakerjaan yakni perintah, pekerjaan, dan upah, namun dalam beberapa literatur juga disebutkan adanya unsur waktu (tjid). Keabsahan hubungan kerja bergantung pada ketiga unsur yang telah diatur dalam Undang-Undang Ketenagakerjaan apakah sudah terpenuhi atau tidak. Hal yang sedikit berbeda terdapat pada hubungan kerja yang dilakukan antara perusahaan pemberi kerja dengan pekerja anak, yakni terdapat peran orang tua atau wali sebagai wakil bagi anak untuk melakukan perbuatan hukum termasuk pada saat melakukan perjanjian kerja. Tak hanya pada saat perjanjian kerja peran orang tua atau wali menjadi esensial, melainkan pada saat berjalannya hubungan kerja antara perusahaan pemberi kerja dengan anak orang tua atau wali menjalankan perannya yakni melaksanakan pengawasan secara langsung baik pada hubungan kerja maupun pada saat anak melangsungkan pekerjaan.

Seperti yang telah terurai diatas bahwa keabsahan hubungan kerja diukur dari terpenuhi atau tidaknya ketiga unsur hubungan kerja dalam Undang-Undang Ketenagakerjaan, begitu pula dengan hubungan kerja yang terjalin antara perusahaan pemberi kerja dan pekerja anak. Dalam hal ini atlet e-Sports dibawah umur dan perusahaan pemberi kerja telah memenuhi unsur-unsur hubungan kerja yakni perintah, pekerjaan, dan upah. Pemenuhan unsur hubungan kerja tentu tak dapat mengenyampingkan syarat-syarat khusus bagi pekerja anak yakni peran 
orang tua atau wali. Maka dari itu dapat ditarik suatu kesimpulan bahwa hubungan kerja yang terjalin antara atlet -Sports dibawah umur dengan perusahaan pemberi kerja adalah sah menurut hukum.

\section{Daftar Bacaan}

\section{Buku}

A. Qirom Meliala, Pokok-Pokok Hukum Perikatan Beserta Perkembangannya (Liberty 1985).

Agus Yudha Hernoko, Hukum Perjanjian (Kencana 2010).

Aloysius Uwiyono, dkk. Asas-Asas Hukum Perburuhan (RajaGrafindo Persada 2014).

Darza Z. A., Kamus Istilah Bidang Ketenagakerjaan (Delima Baru 2000).

Kertasapoetra, G. et.al., Hukum Perburuhan Bidang Hubungan Kerja (Armico 1990).

Maimun, Hukum Ketenagakerjaan Suatu Pengantar (Pradnya Paramita 2007).

Muhammad Teguh Pangestu, Pokok-Pokok Hukum Kontrak (Social Politic Genius 2019).

Oemar Moechtar, Teknik Pembuatan Akta Badan Hukum dan Badan Usaha di Indonesia, (Airlangga University Press 2019).

R Subekti, Hukum Perjanjian (Intermasa 1987).

R.M. Suryodiningnrat, Asas-Asas Hukum Perikatan (Tarsito 1985).

Tim Dosen Hukum Dagang Fakultas Hukum Universitas Airlangga, Buku Ajar Hukum Dagang (Departemen Hukum Perdata Fakultas Hukum Universitas Airlangga Surabaya 2011).

Tim Dosen Hukum Perseroan Fakultas Hukum Universitas Airlangga, Buku Ajar Hukum Perseroan (Koleksi Khusus Fakultas Hukum Universitas Airlangga Surabaya 2011).

Wirjono Prodjodikoro, Asas-Asas Hukum Perjanjian (Sumur 1981).

Wiwoho Sudjono, Persetudjuan Perburuhan (Yayasan Badan Penerbit Gadjah 
Mada Yogyakarta 1970).

\section{Jurnal}

Peter Mahmud Marzuki, 'Batas-Batas Kebebasan Berkontrak' (2003) 18 No. 3 Yuridika.

\section{Skripsi}

Nila Vania, Hubungan Kerja Antara Atlit E-Sports Dengan Pengusaha CV Pemberi Kerja (Skripsi pada Program Sarjana Universitas Airlangga 2018) .

\section{Laman}

Chandrataruna, 'Bekraf Buka-bukaan Soal e-Sports di Indonesia', (skygrid, 2019) $<$ https://media.skyegrid.id/bekraf-buka-bukaan-soal-esport-di-indonesia/>, dikunjungi pada 10 Oktober 2020.

Dhiany Nadya Utami, 'Tim Bigetron RA Sabet Rp 2,5 Miliar, Bawa Indonesia Juara Dunia PUBG Mobile', (Bisnis 2019) <https://teknologi.bisnis.com/ $\mathrm{read} / 20191202 / 280 / 1176814 /$ tim-bigetron-ra-sabet-rp25-miliar-bawaindonesia-juara-dunia-pubg-mobile\#: :text=Bigetron $\% 20$ mendapatkan $\% 20$ trofi $\% 20$ dan $\% 20$ hadiah,di\%20kompetisi $\% 20$ tingkat $\% 20$ Asia $\% 20$ Tenggara $>$, dikunjungi pada tanggal 25 Oktober 2020.

Dimas Hutomo, ‘Adakah Landasan Hukum E-Sports di Indonesia?' (hukumonline, 2018)<www.hukumonline.com>, dikunjungi pada tanggal 1 September 2020.

Ellavie Ichlasa Amalia, 'Seperti Apa Kondisi Bursa Transfer dan Kontrak Pemain e-Sports?', (Hybrid, 2020) <https://hybrid.co.id/post/seperti-apa-kondisibursa-transfer-dan-kontrak-pemain-esports $>$ dikunjungi pada 10 Oktober 2020.

Hanif Sri Yulianto, 'Indonesia Raih Peringkat Kedua PES League World Finals 2019', (Bola, 2019) <https://www.bola.com/e-Sports/read/4002238/indonesiaraih-peringkat-kedua-pes-league-world-finals-2019\#: :text=Indonesia $\% 20$ Raih \%20Peringkat\%20Kedua\%20PES\%20League\%20 World\%20 Finals\%202019,-Hanif\%20Sri\%20Yulianto\&text=Rizky\%20Faidan\%20 tersisih\%20pada\%20fase,juara\%20dunia\%20sebanyak\%20dua\%20kali>, diakses pada 9 September 2020.

Hariyanto, 'Inilah Pengertian Pengusaha dan Bedanya dengan Wirausaha', (Ajaib, 2019) <https://ajaib.co.id/inilah-pengertian-pengusaha-dan-bedanya-denganwirausaha/>, dikunjungi pada 14 Oktober 2020. 
Kibezaka, 'Pantau Berapa Gaji Pemain RRQ HoshiMobile Legends', (Kibezaka 2020) <https://www.kibezaka.com/2020/04/pantau-berapa-gaji-pemain-rrqhoshi.html> dikunjungi pada tanggal 26 Oktober 2020.

Martini, 'CEO RRQ Bongkar Nominal Gaji Pro Player: Hampir Seratus Juta!', (Indosport 2020) <https://www.indosport.com/esports/20200517/ceo-rrqbongkar-nominal-gaji-pro-player-hampir-seratus-juta $>$,dikunjungi pada tanggal 26 Oktober 2020.

Nugyasa Laksamana, 'Besarnya Peluang Usaha dan Profesi Dunia e-Sports di Indonesia' (kompas, 2018) <https://bola.kompas.com/ $\mathrm{read} / 2018 / 12 / 23 / 18450078 /$ besarnya-peluang-usaha-dan-profesi-dunia-eSports-di-indonesia?page=all $>$, dikunjungi pada 10 Oktober 2020.

Taufiq Bagaskara, 'Ini Dia Biodara dan Profil BTR Zuxxy Player dari Bigetron eSports' (Grid, 2019) < https://games.grid.id/read/151777027/ini-dia-biodatadan-profil-btr-zuxxy-player-dari-bigetron-esports?page=all $>$,dikunjungi pada 12 September 2020.

Yabes Elia, 'Antara Sponsor, Tim, dan Event e-Sports: Sebuah Pengantar' (Hybrid, 2018) <https://hybrid.co.id/post/antara-sponsor-tim-dan-event-esportssebuah-pengantar $>$, dikunjungi pada 20 Oktober 2020.

Yuslianson, 'Bigetron RA Juarai PMCO Fall Split Global Finals 2019, Kantongi Rp 2,8 Miliar'(Liputan 6, 2019) <https://www.liputan6.com/tekno/read/4124063/ bigetron-ra-juarai-pmco-fall-split-global-finals-2019-kantongi-rp-28miliar\#: :text=Game-,Bigetron\%20RA\%20Juarai\%20PMCO\%20 Fall\%20Split\%20Global\%20Finals,Kantongi\%20Rp\%202\%2C8\%20 Miliar\&text=Liputan6.com\%2C\%20Jakarta\%20\%2D\%20Bigetron,Fall\%20 Split\%20Global\%20Finals\%202019>, diakses pada 12 September 2020.

\section{Peraturan Perundang-undangan}

Kitab Undang-Undang Hukum Dagang (Wetboek van Koophandel).

Kitab Undang-Undang Hukum Perdata (Burgerlijk Wetboek).

Undang-Undang Republik Indonesia Nomor 20 Tahun 1999 tentang Pengesahan ILO Convention No. 138 Concerning Minimum Age For Admission To Employment (Konvensi ILO Mengenai Usia Minimum Untuk Diperbolehkan Bekerja), Lembaran Negara Republik Indonesia Tahun 1999 Nomor 56, Tambahan Lembaran Negara Republik Indonesia Nomor 3835.

Undang-Undang Nomor 13 Tahun 2003 tentang Ketenagakerjaan, Lembaran Negara Republik Indonesia Tahun 2003 Nomor 39, Tambahan Lembaran 
Negara Republik Indonesia Nomor 4279.

Undang-Undang Republik Indonesia Nomor 2 Tahun 2004 tentang Penyelesaian Perselisihan Hubungan Industrial, Lembaran Negara Republik Indonesia Tahun 2004 Nomor 6, Tambahan Lembaran Negara Republik Indonesia Nomor 4356.

Undang-Undang Republik Indonesia Nomor 3 Tahun 2005 tentang Sistem Keolahragaan Nasional, Lembaran Negara Republik Indonesia Tahun 2005 Nomor 89, Tambahan Lembaran Negara Republik Indonesia Nomor 4535.

Peraturan Presiden Nomor 6 Tahun 2015 tentang Badan Ekonomi Kreatif, Lembaran Negara Republik Indonesia Tahun 2015 Nomor 7, juncto Peraturan Presiden Nomor 72 Tahun 2015 tentang Perubahan atas Peraturan Presiden Nomor 6 Tahun 2015 tentang Badan Ekonomi Kreatif, Lembaran Negara Republik Indonesia Tahun 2015 Nomor 139.

Peraturan Pemerintah Republik Indonesia Nomor 78 Tahun 2015 tentang Pengupahan, Lembaran Negara Republik Indonesia Tahun 2015 Nomor 237, Tambahan Lembaran Negara Republik Indonesia Nomor 5747.

Keputusan Menteri Ketenagakerjaan dan Transmigrasi Republik Indonesia Nomor KEP. 235/MEN/2003 tentang Jenis-Jenis Pekerjaan yang Membahayakan Kesehatan, Keselamatan atau Moral Anak.

Keputusan Menteri Ketenagakerjaan dan Transmigrasi Nomor KEP. 115/MEN/ VII/2004 tentang Perlindungan Bagi Anak yang Melakukan Pekerjaan Untuk Mengembangkan Bakat dan Minat. 
I Putu: Keabsahan Hubungan Kerja...

--halaman ini sengaja dibiarkan kosong-- 